\title{
Article \\ Effects of Elevated Temperature on Root System Development of Two Lupine Species
}

\author{
Virgilija Gavelienè *, Sigita Jurkonienė *(D), Elžbieta Jankovska-Bortkevič $\mathbb{C}$ and Danguolè Švegždienè
}

\author{
Nature Research Centre, Institute of Botany, Akademijos Str. 2, 08412 Vilnius, Lithuania; \\ elzbieta.jankovska@gamtc.lt (E.J.-B.); dangasv@gmail.com (D.Š.) \\ * Correspondence: virgilija.gaveliene@gmail.com (V.G.); sigita.jurkoniene@gamtc.lt (S.J.)
}

check for updates

Citation: Gavelienè, V.; Jurkonienè,

S.; Jankovska-Bortkevič, E.;

Švegždienè, D. Effects of Elevated

Temperature on Root System

Development of Two Lupine Species.

Plants 2022, 11, 192. https://

doi.org/10.3390/plants11020192

Academic Editor: James Bunce

Received: 22 December 2021

Accepted: 8 January 2022

Published: 12 January 2022

Publisher's Note: MDPI stays neutral with regard to jurisdictional claims in published maps and institutional affiliations.

Copyright: (C) 2022 by the authors. Licensee MDPI, Basel, Switzerland. This article is an open access article distributed under the terms and conditions of the Creative Commons Attribution (CC BY) license (https:/ / creativecommons.org/licenses/by/ $4.0 /)$.

\begin{abstract}
The aim of this study was to assess the effect of elevated temperature on the growth, morphology and spatial orientation of lupine roots at the initial stages of development and on the formation of lupine root architecture at later stages. Two lupine species were studied-the invasive Lupinus polyphyllus Lindl. and the non-invasive L. luteus L. The plants were grown in climate chambers under $25{ }^{\circ} \mathrm{C}$ and simulated warming at $30{ }^{\circ} \mathrm{C}$ conditions. The angle of root curvature towards the vector of gravity was measured at the 48th hour of growth, and during a 4-h period after $90^{\circ}$ reorientation. Root biometrical, histological measurements were carried out on 7-day-old and 30-day-old plants. The elevation of $5{ }^{\circ} \mathrm{C}$ affected root formation of the two lupine species differently. The initial roots of L. polyphyllus were characterized by worse spatial orientation, reduced growth and reduced mitotic index of root apical meristem at $30{ }^{\circ} \mathrm{C}$ compared with $25{ }^{\circ} \mathrm{C}$. The length of primary roots of 30-day-old lupines and the number of lateral roots decreased by $14 \%$ and $16 \%$, respectively. More intense root development and formation were observed in non-invasive L. luteus at $30{ }^{\circ} \mathrm{C}$. Our results provide important information on the effect of elevated temperature on the formation of root architecture in two lupine species and suggest that global warming may impact the invasiveness of these species.
\end{abstract}

Keywords: gravitropic angle of curvature; initial root; invasiveness; lateral root number; primary root; root system architecture; simulated warming

\section{Introduction}

The world is experiencing ongoing global climate change, which can have serious consequences on plants, including changes in the availability of certain nutrients. For understanding the effects of climate warming on plant root systems, particularly their spatial distribution, it is essential to predict plant performance and community recovery in a warming climate. Compared with shoots, much less is known about how roots, especially root system architecture (RSA), may respond to elevated temperature. In addition, limited information is available on the specificities of the effects of elevated temperatures on the development of the root system in invasive plants. How does an increase in temperature change the intensity and the direction of root formation? To answer this question, researchers have compared the responses of plants with different RSAs in their studies [1,2]. The ability of a plant to take up nutrients is closely associated with the size and morphology of its root system [1,3]. Any changes in the growth or morphological modifications of root systems may provoke undesirable consequences in nutrient uptake [4]. It is recognized that many aspects of plant metabolism are accelerated by elevated temperatures $[5,6]$. Other environmental factors such as water, nutrients and temperature also have a strong influence on root structure [7]. Roots need an optimal temperature range to have a proper growth rate and function. In general, the optimal root temperature tends to be lower than the optimal shoot temperature $[8,9]$. It is evident that the optimum root temperature of plants varies depending on the species. Within this range, higher temperatures are generally associated 
with modified root-to-shoot ratios, while further increases in temperature would reduce root development and cause a change in RSA, thus reducing the root-to-shoot ratio [10]. For instance, some plants tend to produce more extensive root systems in elevated temperatures. An increase in temperature slows down lateral root growth in adult maize plants and promotes the development of long axial roots to reach deeper soil layers for water [11,12]. However, in potatoes, the initiation and elongation of adventitious and lateral roots were inhibited by increasing temperature. Another effect of warmer soil on potatoes is the swelling of the root cap meristem and the bending of the root tip. The alteration of root growth in these plants appeared due to a reduced rate of cell division $[13,14]$. Similarly, in sorghum, the high root zone temperature reduced the rate of root elongation and cell production rate [15]. The response of RSA to elevated temperature can be species-specific, as different species often have different optimum temperatures for root growth $[16,17]$. Literature data show that the effect of increasing temperature on root growth of plant seedlings can be promotive, inhibitive or first promotive then inhibitive after an optimum temperature is reached $[18,19]$. Even for species sharing the same habitat, their RSA can have species-specific responses to increased temperature [20]. Differences in the RSA of plant species may determine the intensity and direction of root formation in response to elevated temperatures. At high temperatures, the negative root response may have been intensified, with a competitive advantage going to species with larger and more rapidly forming roots.

Literature data indicate that greater root resilience plays a key role in plants adapting to high temperatures [21-23] in all stages of root development, including tropisms and the formation of new organs [24,25]. Furthermore, the oriented plant growth, which is collectively referred to as tropism [26,27], is influenced by various environmental factors, such as light, temperature, water and gravity. Gravitropism is an important tropic response that triggers asymmetric cell elongation in plant organs in response to gravity. It proceeds through three sequential steps: gravity perception, signal transduction and asymmetric cell elongation in the responding plant organs [28,29]. The roots grow downward, and the shoots grow upward, showing positive and negative gravitropic responses, respectively [30,31]. The well-known Cholodny-Went hypothesis illustrates that gravitropic stimuli result in differential cell elongation in the responding organs [32-35]. It has been shown that gravitropic perception occurs in the columella cells in the roots upon gravity stimulation [36,37]. The gravitropic response of plant organs is influenced by a variety of environmental signals. The best understood are the effects of light and temperature. Many scientists agree that climate change will alter habitat biodiversity and increase vulnerability to invasion. However, there is little information on the impact of potentially increasing global temperatures on the growth and development of alien plant species at the early stages of development. Moreover, one of the selected lupine species is invasive in Lithuania, L. polyphyllus, and there is very limited information on the specificities of the effect of elevated temperatures on the root system development of invasive plants. Therefore, in this research, RSA traits of seedlings of two lupine species (L. polyphyllus and L. luteus) with different spreading performances for understanding their responses to temperature change were studied. We hypothesized that increased temperature may differentially affect root growth, spatial orientation and root architecture of non-native plant species, thereby influencing them to become invasive. Studies on plant root system adaptive responses to altered temperature can provide the knowledge needed for the efficient management of invasive species. Thus, the goal of the current study was to investigate root growth, morphology and spatial orientation of two alien lupine species during the early growth stage at the elevated temperature. 


\section{Results}

\subsection{The Initial Root Growth at $25^{\circ} \mathrm{C}$ and $30^{\circ} \mathrm{C}$}

\subsubsection{Angle of Curvature of Initial Roots at $25^{\circ} \mathrm{C}$ and $30{ }^{\circ} \mathrm{C}$}

After $48 \mathrm{~h}$ of seedling growth, the spatial orientation and growth direction of the roots of both lupines depended on the temperature: the angle of curvature of the primary roots of the invasive L. polyphyllus with respect to the gravitational vector was $6.2^{\circ}$ at $25^{\circ} \mathrm{C}$, and $20.8^{\circ}$ at $30^{\circ} \mathrm{C}$. The initial roots of the non-invasive L. luteus showed a better orientation towards the gravity vector at $30^{\circ} \mathrm{C}$ (Table 1 , Figure 1 ).

Table 1. Influence of $25^{\circ} \mathrm{C}$ and $30{ }^{\circ} \mathrm{C}$ temperatures on the angle of curvature of the initial roots of L. polyphyllus and L. luteus seedlings grown vertically for $48 \mathrm{~h}$.

\begin{tabular}{ccccc}
\hline Plant Species & \multicolumn{2}{c}{ Lupinus polyphyllus } & \multicolumn{2}{c}{ Lupinus luteus } \\
\hline Temperature & $25^{\circ} \mathrm{C}$ & $30^{\circ} \mathrm{C}$ & $25^{\circ} \mathrm{C}$ & $30{ }^{\circ} \mathrm{C}$ \\
Angle of curvature, degrees & $6.2 \pm 0.53 \mathrm{a}$ & $20.8 \pm 0.95 \mathrm{~b}$ & $14.2 \pm 1.21 \mathrm{C}$ & $6.8 \pm 0.43 \mathrm{a}$
\end{tabular}

Values presented are the mean values of four replications with standard deviation. Different lowercase letters indicate significant differences between test variants at $p<0.05$.

$25^{\circ} \mathrm{C} \quad$ Lupinus polyphyllus $\quad 30^{\circ} \mathrm{C}$
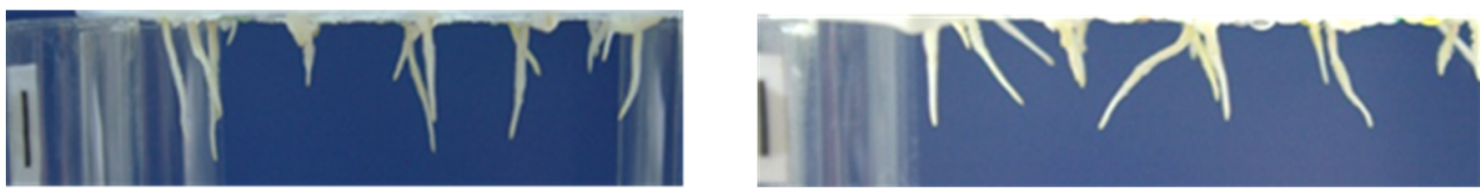

$25^{\circ} \mathrm{C}$

Lupinus luteus

$30^{\circ} \mathrm{C}$
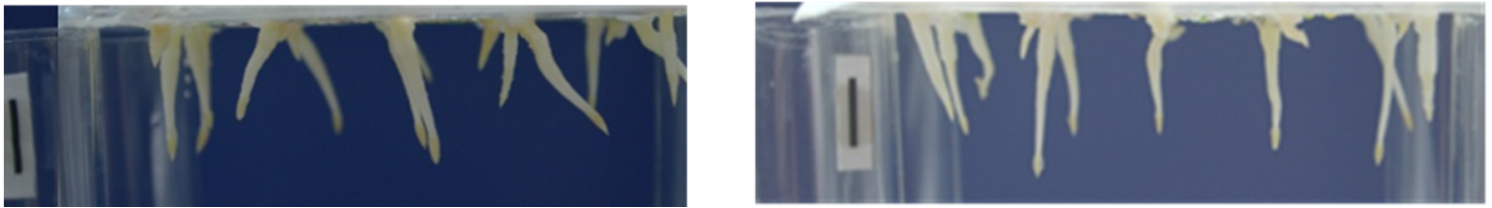

Figure 1. Spatial orientation of the initial roots of L. polyphyllus and L. luteus seedlings at $25^{\circ} \mathrm{C}$ and $30{ }^{\circ} \mathrm{C}$ after $48 \mathrm{~h}$. Scale bar, $10 \mathrm{~mm}$.

\subsubsection{Gravitropic Response of Initial Roots to $90^{\circ}$ Reorientation}

The strongest root response to gravitropic irritation in both lupine species was found to occur within the first hour. The gravitropic bending of L. polyphyllus roots after $1 \mathrm{~h}$ was $16^{\circ}$ greater at $25{ }^{\circ} \mathrm{C}$ than at $30^{\circ} \mathrm{C}$. The gravitropic bending of L. luteus roots was more intensive at $30^{\circ} \mathrm{C}$. The gravitropic response of the roots of both lupine species to a $90^{\circ}$ reorientation was closer to the direction of gravity after $4 \mathrm{~h}$ (Figure 2).

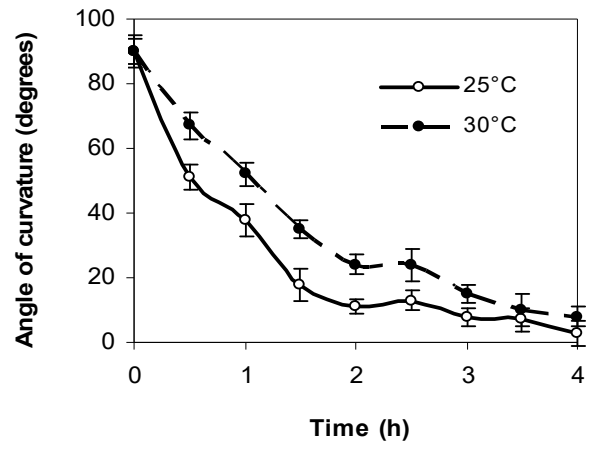

(a)

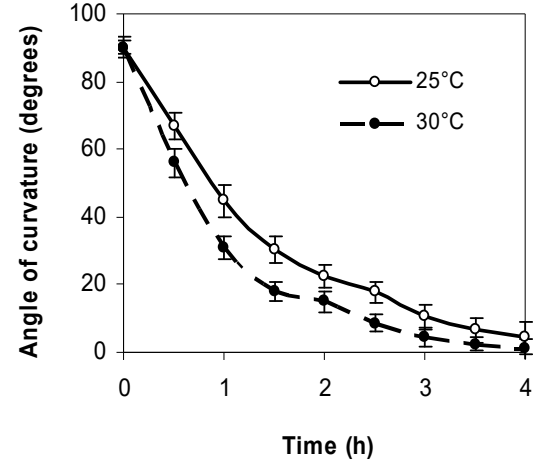

(b)

Figure 2. The dynamics of gravitropic response of L. polyphyllus (a) and L. luteus (b) roots to $90^{\circ}$ reorientation at $25^{\circ} \mathrm{C}$ and $30^{\circ} \mathrm{C}$. 


\subsubsection{Growth of Primary Roots of 7-Day-Old Seedlings at $25^{\circ} \mathrm{C}$ and $30{ }^{\circ} \mathrm{C}$}

Morphometric studies showed that the length of roots of the invasive lupine grown at $30{ }^{\circ} \mathrm{C}$ for seven days was approximately $12 \%$ lower than that of the plants grown at $25^{\circ} \mathrm{C}$ (Figure 3), while the roots of the non-invasive lupine grew up to $13 \%$ longer at $30^{\circ} \mathrm{C}$.

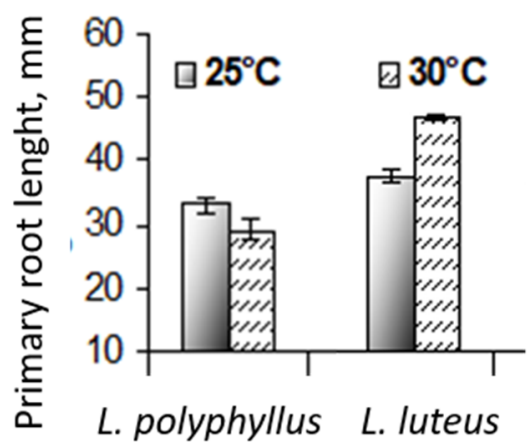

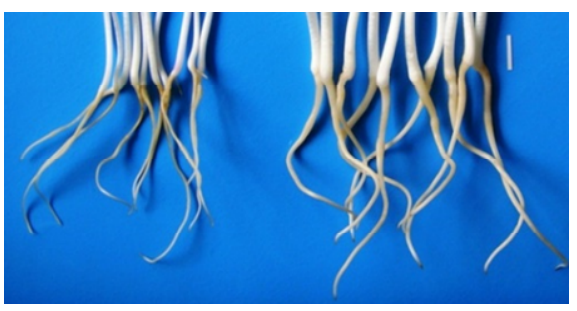

$25^{\circ} \mathrm{C}$

L. polyphyllus L.luteus

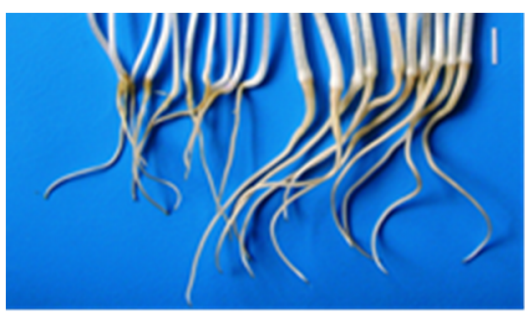

$30{ }^{\circ} \mathrm{C}$

Figure 3. Effect of $25^{\circ} \mathrm{C}$ and $30^{\circ} \mathrm{C}$ temperature on root growth parameters of seven-day-old seedlings of two lupine species. Scale bar, $10 \mathrm{~mm}$.

We found that the root-to-shoot ratio of both species decreased at $30{ }^{\circ} \mathrm{C}$ (Table 2). This index, in the case of L. polyphyllus, decreased crucially by $65 \%$ and in the case of L. luteus by $22 \%$.

Table 2. Influence of $25{ }^{\circ} \mathrm{C}$ and $30{ }^{\circ} \mathrm{C}$ temperature on root-to-shoot ratio of the seven-day-old seedlings of L. polyphyllus and L. luteus.

\begin{tabular}{ccccc}
\hline Plant Species & \multicolumn{2}{c}{ Lupinus polyphyllus } & \multicolumn{2}{c}{ Lupinus luteus } \\
\hline Temperature & $25^{\circ} \mathrm{C}$ & $30^{\circ} \mathrm{C}$ & $25^{\circ} \mathrm{C}$ & $30{ }^{\circ} \mathrm{C}$ \\
Root-to-shoot ratio & $0.182 \pm 0.03 \mathrm{a}$ & $0.063 \pm 0.01 \mathrm{~b}$ & $0.217 \pm 0.03 \mathrm{a}$ & $0.169 \pm 0.01 \mathrm{a}$ \\
\hline
\end{tabular}

Values presented are the mean values of four replications with standard deviation. Different lowercase letters indicate significant differences between test variants, at $p<0.05$.

\subsubsection{Root Apex Development at $25^{\circ} \mathrm{C}$ and $30^{\circ} \mathrm{C}$}

Cytomorphological analysis of the root cap columella of L. polyphyllus showed that the length of the cells in the individual rows of the columella varied with temperature (Figure 4). From the seventh row of the columella onwards, cell length increased more at $25{ }^{\circ} \mathrm{C}$ than at $30^{\circ} \mathrm{C}$. The changes in cell length in the L. luteus columella were substantially different from that of L. polyphyllus. The cell length of the columella at $30^{\circ} \mathrm{C}$ was greater starting from the second row onwards. This trend was observed in all the following rows.

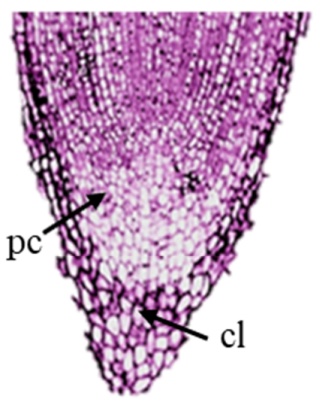

L. polyphyllus

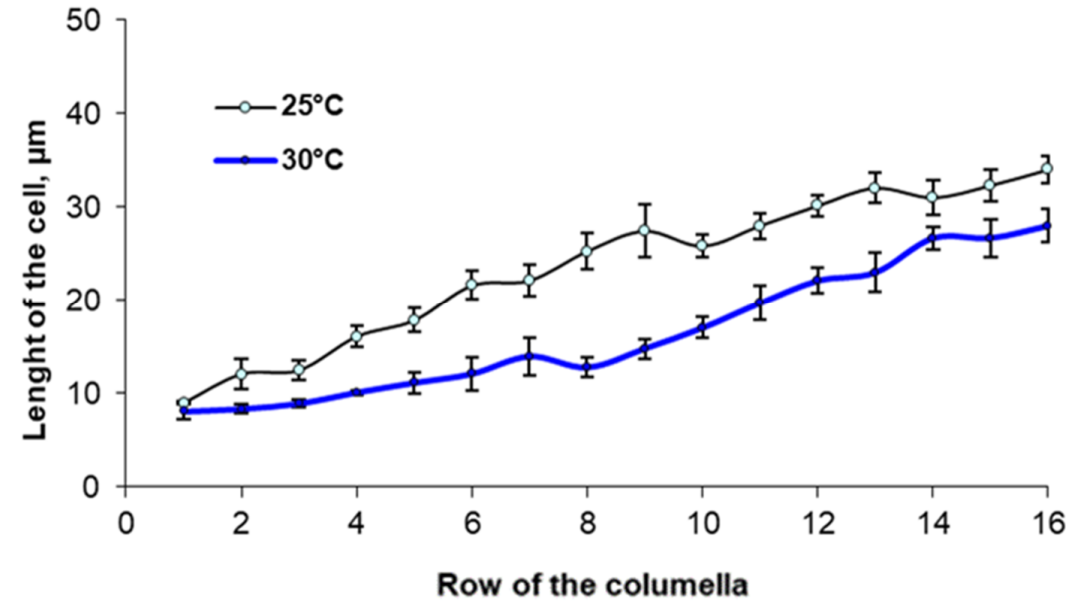

Row of the columella

Figure 4. Cont. 

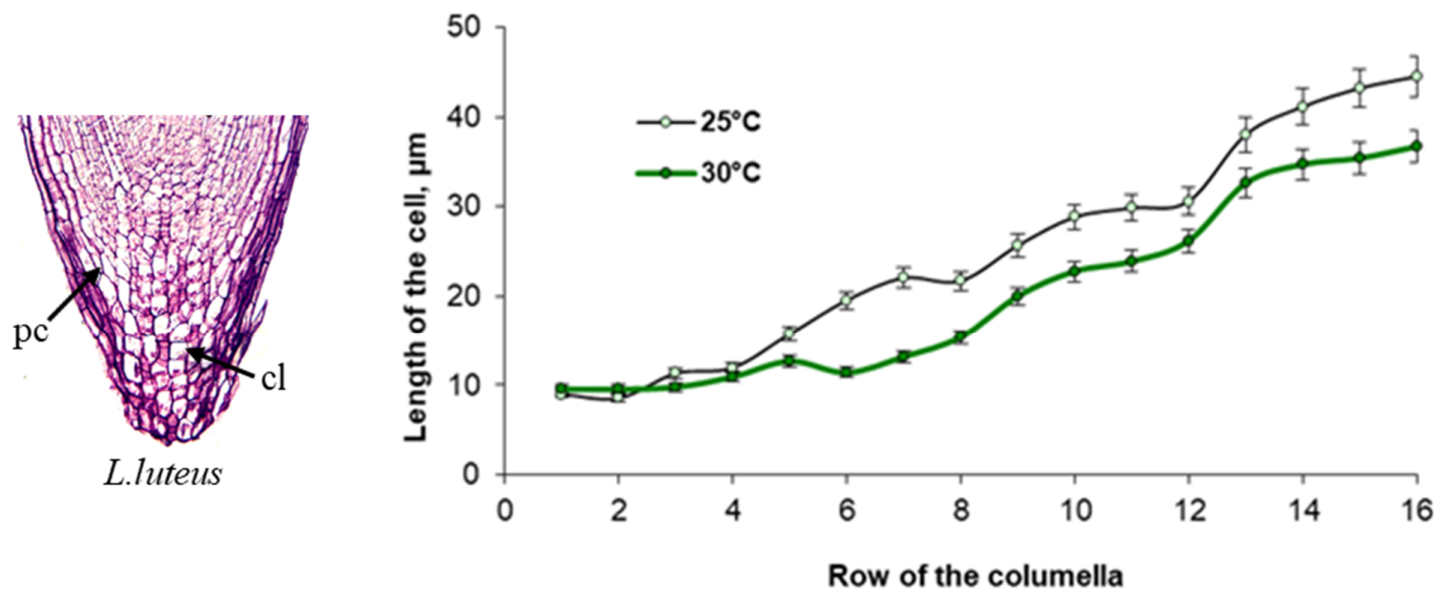

Figure 4. Impact of $25^{\circ} \mathrm{C}$ and $30^{\circ} \mathrm{C}$ temperature on the length of cells in the columella (cl) rows of the primary root cap (pc) (from the initial cells) of L. polyphyllus and L. luteus.

Determination of the cell division mitotic index (MI) in L. polyphyllus root apical meristem preparations showed that the cell MI value decreased by $12 \%$ in the test variant at $30{ }^{\circ} \mathrm{C}$ as compared with $25{ }^{\circ} \mathrm{C}$ (Figure 5a). Contrary, the calculation of MI in the non-invasive L. luteus root apical meristem indicated a significant increase at $30^{\circ} \mathrm{C}$. By observing the cross-sections of the invasive lupine root apex, we determined that meristem cells occurred in the prophase, metaphase and some even in the anaphase in the test variant at $25^{\circ} \mathrm{C}$, whereas most cells of plants grown at $30^{\circ} \mathrm{C}$ were found in the prophase (Figure $5 b$ ).

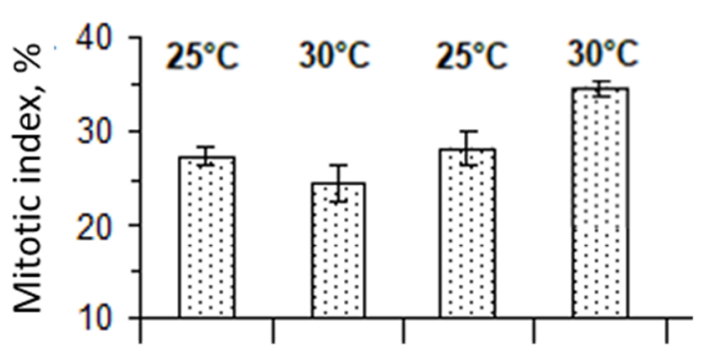

L. polyphyllus L. luteus

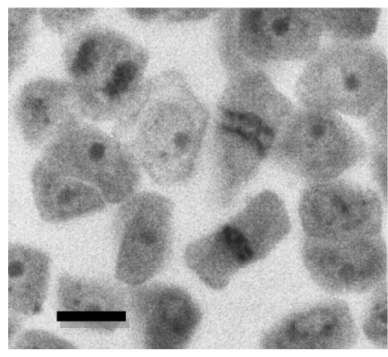

$25^{\circ} \mathrm{C}$

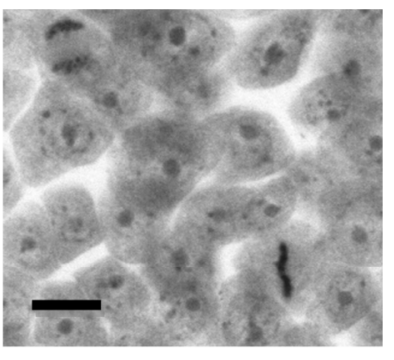

$30^{\circ} \mathrm{C}$

(a)

(b)

Figure 5. Effect of $25^{\circ} \mathrm{C}$ and $30^{\circ} \mathrm{C}$ temperatures on L. polyphyllus and L. luteus root apex meristem cells mitotic activity (a), fragments of primary root apical meristem pressed preparations from L. polyphyllus seedlings (b). Scale bar, $20 \mu \mathrm{m}$.

\subsection{The Development of 30 -Day-Old Lupine Roots at $25^{\circ} \mathrm{C}$ and $30^{\circ} \mathrm{C}$}

The data of the morphometric measurements showed that simulated $5{ }^{\circ} \mathrm{C}$ warming affected invasive Lupinus polyphyllus root formation:primary root length decreased by $14 \%$ and the number of lateral roots by $16 \%$. The length of the primary root and the number of lateral roots of non-invasive L. luteus were higher at $30^{\circ} \mathrm{C}$ (Figures 6 and 7 ). 
A

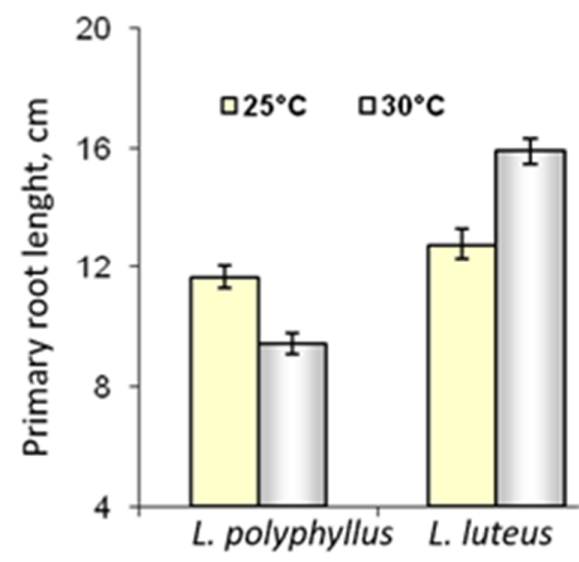

B

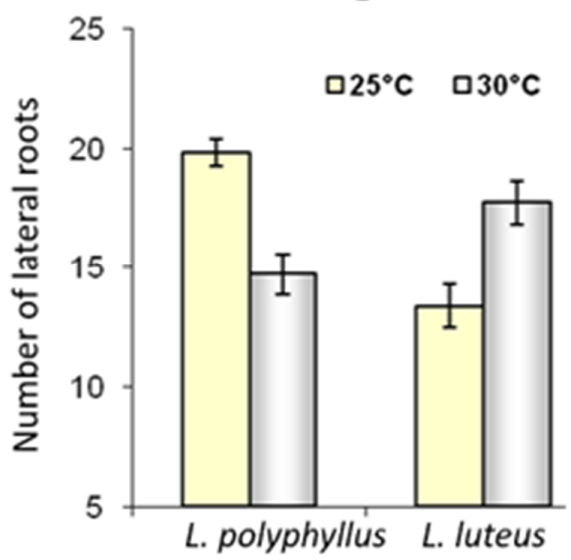

Figure 6. Effect of $25^{\circ} \mathrm{C}$ and $30^{\circ} \mathrm{C}$ temperature on the length of primary roots (A) and the number of lateral roots (B) of invasive L. polyphyllus and non-invasive L. luteus plants grown in soil for 30 days.

\section{$25{ }^{\circ} \mathrm{C} \quad$ Lupinus polyphyllus $\quad 30{ }^{\circ} \mathrm{C}$}
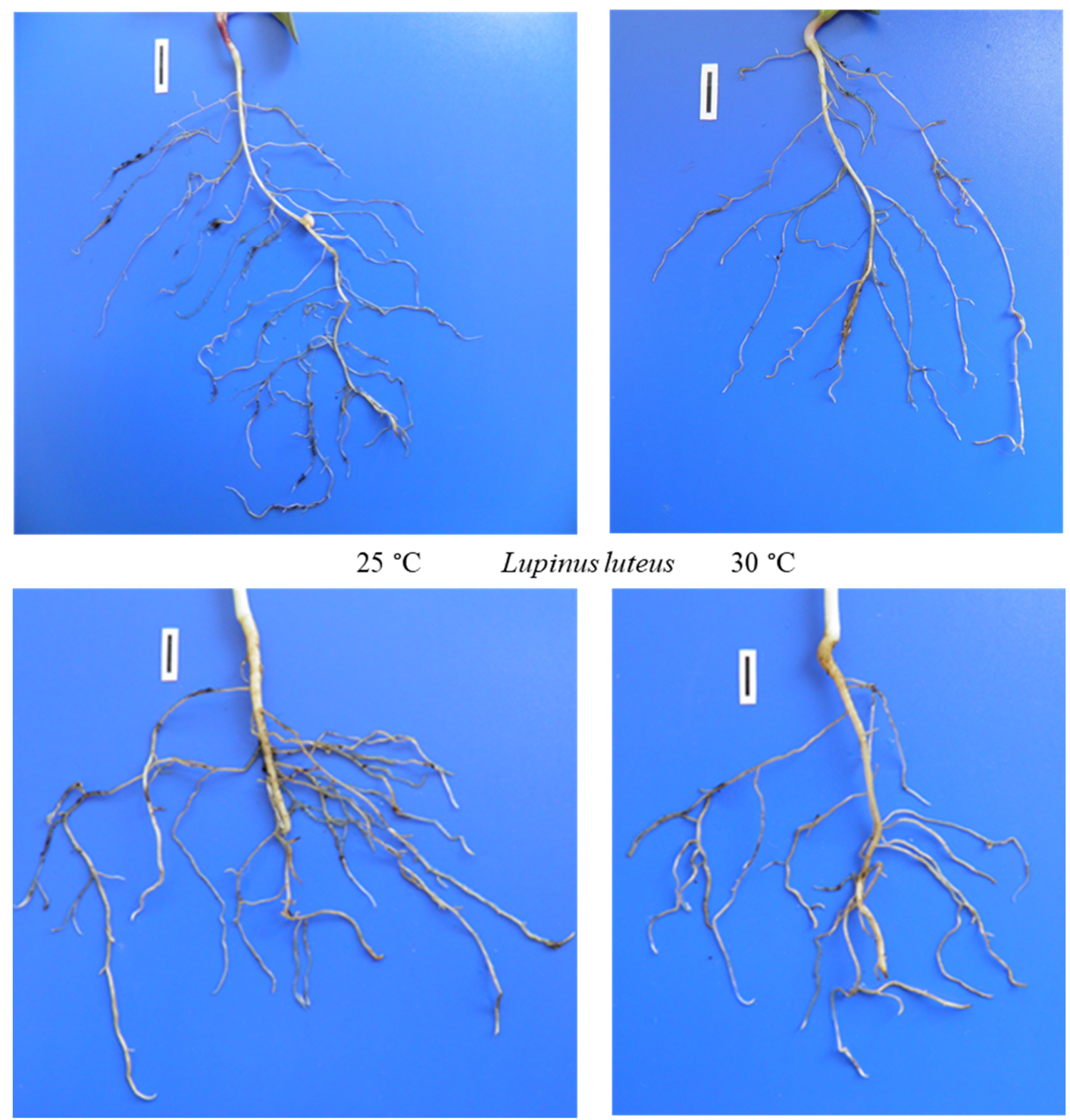

Figure 7. Roots of invasive L. polyphyllus and non-invasive L. luteus grown in the soil for 30 days. Scale bar, $10 \mathrm{~mm}$. 


\section{Discussion}

Temperature is one of the most important variables affecting plant growth. The effect of elevated temperature on aboveground plant parts has been well studied, while the effect on roots is less understood [2,17]. Roots need an optimal temperature range to grow and function properly. In general, the optimum root temperature is usually lower than the optimum shoot temperature. Literature shows that the effect of increasing temperature on root growth of plant seedlings can be either stimulatory, inhibitory or, once the optimum temperature is reached, initially stimulatory and then inhibitory $[9,38,39]$. In particular, it is important to study plants with different RSAs to understand the response of root development to temperature changes [1,2]. During seed germination, the growth of the seedling's primary root and its ability to orient itself in space (gravitropism) are critical characteristics for seedling establishment and survival [35]. To answer the question of whether there are differences in the ability of the primary root of the two lupine species to respond to gravity and whether elevated temperature influences this process, an analysis of the direction of root growth in relation to gravity was conducted. This study showed that after $48 \mathrm{~h}$ of growth, the spatial orientation and subsequent growth direction of both lupine roots depended on the ambient temperature:angle of curvature of the initial roots of the invasive L. polyphyllus, with respect to the gravitational vector, was $6.2^{\circ}$ at $25^{\circ} \mathrm{C}$, and $20.8^{\circ}$ at $30^{\circ} \mathrm{C}$. Thus, the initial roots of the non-invasive L. luteus were better oriented towards the Earth's gravity vector at $30^{\circ} \mathrm{C}$.

The vertical orientation of emerging roots is typically the first response of plants to gravity $[40,41]$. Sensing of the gravity stimulus ultimately triggers a signaling network orchestrated by the phytohormone auxin, which is key to the coordination of directional root growth in response to gravity [42-44]. Although root gravitropism has been studied extensively, no conclusive data on the onset of gravisensing is established. The inception of gravisensitivity in flowering plant roots after various periods of static orientation (gravistimulation) of imbibed seeds was studied [7,37,43]. Their results indicate that after gravistimulation $\left(90^{\circ}\right.$ reorientation), gravitropic bending of flowering plant roots was established in $6 \mathrm{~h}$ along the gravity vector. These results well coincide with ours. Our data showed that after $1 \mathrm{~h}$ of gravistimulation ( $90^{\circ}$ reorientation), the gravitropic bending of L. polyphyllus roots was $16^{\circ}$ greater at $25{ }^{\circ} \mathrm{C}$ than at $30^{\circ} \mathrm{C}$; differently, the L. luteus roots response was more intensive at $30^{\circ} \mathrm{C}$. The gravitropic response of the initial roots of both lupine species to a $90^{\circ}$ reorientation was closer to the direction of gravity after $4 \mathrm{~h}$, both at $25^{\circ} \mathrm{C}$ and at $30^{\circ} \mathrm{C}$. These data suggest that the initial roots of invasive lupines are less able to grow in the gravitational direction in a $5{ }^{\circ} \mathrm{C}$ warmer environment. Thus, dependence between the increase of environmental temperature and the inception of root gravitropic competence was determined. However, these parameters are not applicable to the description of RSA with complex geometry.

It has been shown that the effect of elevated temperature on the root growth of plant seedlings can be either activating or inhibiting in plants with a higher proportion of roots [2]. The morphometric tests carried out in this study showed that after seven days, the primary root growth of invasive lupines slowed down by $12 \%$ at $30{ }^{\circ} \mathrm{C}$ as compared to plants grown at $25{ }^{\circ} \mathrm{C}$, while the root growth of non-invasive lupines accelerated by $13 \%$ at $30{ }^{\circ} \mathrm{C}$. Elevated temperature is associated with a reduced root-to-shoot ratio, and a further increase in temperature limits root development and alters RSA [10]. We determined that the root-to-shoot ratio was reduced in both species at $30^{\circ} \mathrm{C}$; however, the roots of L. luteus were less sensitive to warming temperatures. It was obvious that this index, in the case of L. polyphyllus, decreased crucially.

Literature data indicate that the size of the root cap, the proportion of the columella in a root cap and meristem cell division were related to the growth of the roots [44,45]. It is known that the apical root growth correlated with the size of the columella and the number of cap cells in the plant root apex [46]. An increase in temperature promotes the initial growth of the roots of Arabidopsis seedlings and, at the same time, affects the elongation of columella cells [40]. In the current study, cytomorphological analysis of the root cap 
columella of L. polyphyllus showed that the length of the cells in the individual rows of the columella varied with temperature (Figure 4 ) - the increase of columella cell length was more intensive at $25^{\circ} \mathrm{C}$ than at $30^{\circ} \mathrm{C}$. Nevertheless, L. polyphyllus cell length was greater at $30{ }^{\circ} \mathrm{C}$ already from the second row of the columella onwards. The apical meristem of roots provides cell regeneration, and the transition zone between the meristem and the cell extension zone enables the apex, directly or indirectly through the secondary signal, to sense changing environmental parameters and respond to changes in cell division [47,48]. Furthermore, anatomical-cytological analysis of apical meristem cells in the invasive lupine root apex showed that cell division was intense at a lower temperature. By observing the cross-sections of root apex, we determined that in the test variant at $25^{\circ} \mathrm{C}$, meristem cells occurred in the prophase, metaphase and some even in the anaphase, whereas most cells of plants grown at $30^{\circ} \mathrm{C}$ were found in the prophase.

The data on differences in root size of L. polyphyllus and L. luteus resulting from temperature change suggests that the elevated temperature may be more difficult for invasive lupines to adapt to. The architecture of the root system is determined by the development of both primary and lateral roots $[49,50]$. The plant root system takes up water and dissolved nutrients from the soil; therefore, the size and extent of the root system have important implications for plant development [7,51]. Our results show that the two species of lupine seedlings grown in the soil for 30 days responded differently to changes in temperature. The most significant changes were observed in root length and lateral root formation. Plants of the invasive lupine had a larger root system at $25{ }^{\circ} \mathrm{C}$, and the root size of non-invasive lupine generally increased at $30^{\circ} \mathrm{C}$. Under the elevated temperature, non-invasive plants produced more extensive root systems.

Our results provide key information concerning the elevated temperature on the formation of root architecture of two lupine species and suggest that the elevated temperature affects species invasiveness. In the early stages of growth (after $48 \mathrm{~h}$ ), the spatial orientation of the initial roots of both lupines depended on the temperature-the angle of curvature of the initial roots of L. polyphyllus was closer to the gravity vector than L. luteus at $25{ }^{\circ} \mathrm{C}$. The initial roots of the non-invasive L. luteus showed a better orientation towards the gravity vector at $30{ }^{\circ} \mathrm{C}$. These processes were important for the subsequent formation of root architecture - the dynamics of gravitropic response of L. polyphyllus and L. luteus initial roots to $90^{\circ}$ reorientation showed that the gravitropic bending of L. luteus roots was more intensive at $30^{\circ} \mathrm{C}$. Simulated warming $\left(5^{\circ} \mathrm{C}\right)$ affected L. polyphyllus root formation as the initial roots were characterized by disrupted gravitropic orientation to the gravity vector; the cell division mitotic index (MI) of root apical meristem decreased by $12 \%$ at $30{ }^{\circ} \mathrm{C}$ as compared with $25^{\circ} \mathrm{C}$. The temperature of $30{ }^{\circ} \mathrm{C}$ triggered the non-invasive L. luteus root development, formation and spatial orientation, both in the initial and later stages of development. After 30 days of growth, seedlings of the two lupine species responded differently to elevated temperature - the invasive lupine formed a larger root system at $25^{\circ} \mathrm{C}$, and the non-invasive lupine root size increased at $30^{\circ} \mathrm{C}$. Bearing in mind that global warming tends to enhance species invasiveness and the northward spread, among other issues, these findings provide important information on the effect of increased temperature on the formation of plant root architecture and suggest that elevated temperature alters the invasiveness of alien species due to changes in root architecture.

\section{Materials and Methods}

\subsection{The Initial Root Growth at $25^{\circ} \mathrm{C}$ and $30^{\circ} \mathrm{C}$}

Two different lupine species_-invasive L. polyphyllus and non-invasive L. luteus [52]—seeds were harvested in a natural environment in Lithuania and used as plant material. Seeds were soaked for $5 \mathrm{~h}$ in tap water at room temperature and then germinated in climate chambers (Climacell, Czech Republic) at $90 \%$ relative humidity in the dark at two different temperatures: at $25{ }^{\circ} \mathrm{C}$ (optimal temperature for lupine) and $30{ }^{\circ} \mathrm{C}$ (simulated climate warming temperature) [53]. For root system architecture exploration, seeds were sown in $7 \mathrm{~cm}$ diameter pots containing a mixture of vegetable compost $90 \%$, peat $9 \%$, ash of 
deciduous trees $1 \%$ and fertilizer NPK and grown 30 days in growth chambers with $12 \mathrm{~h}$ light/dark photoperiod, at $25^{\circ} \mathrm{C}$ and $30^{\circ} \mathrm{C}$.

\subsection{The Measurement of the Angle of Root Curvature}

The assessment of root-growth patterns is based on the measurement of angular deviation of the root tip from the vertical axis. For assay of roots gravitropic response, 30 soaked seeds of both lupines were planted in gaps in transparent plexiglass boxes filled with distilled water so that protruding roots could grow freely downwards, i.e., towards the action of the gravitational force. The seedlings grew in the germinators at $25^{\circ}$ and $30^{\circ} \mathrm{C}$, and relative humidity of $90 \%$ in the dark. The angle of root curvature towards the vector of gravity was measured at the 48th hour of growth.

\subsection{Determination of Gravitropic Response of Roots to $90^{\circ}$ Reorientation}

Seeds were germinated on wet filter paper for $21 \mathrm{~h}$ and then planted on a sterile control medium $(1 \%$ agar $[w / v])$ in square Petri dishes. The seeds with initial roots were fastened by agar and oriented so that roots could orient freely along the agar surface for $24 \mathrm{~h}$ in a vertical orientation. The dynamics of root curvature as an angle towards the gravitropic vector were measured at the 4-h period of the reorientation in a 90-degree position.

\subsection{Morphometrical Tests}

Measurements of root length and root-to-shoot ratio were performed on 7-day-old seedlings grown in tap water in the dark at $25^{\circ} \mathrm{C}$ and $30^{\circ} \mathrm{C}$. The length of the primary root and the number of lateral roots of the two species of lupine were measured after 30 days of growth at $25^{\circ} \mathrm{C}$ and $30^{\circ} \mathrm{C}$ in soil.

\subsection{Anatomical-Cytometrical Analysis of Primary Root Development}

\subsubsection{Cytometrical Investigations}

Primary roots were excised from roots of 10 seedlings (7-day-old). The prepared samples were fixed in a formalin:acetic acid:ethanol (1:1:20) (FAA) mixture, dehydrated in a graded ethanol series, embedded in paraffin and cut with a rotary microtome Leica RM2125 into 10-15 $\mu \mathrm{m}$ sections. Serial longitudinal sections were stained with periodic acid-Schiff's reagent, and the length of statocytes in the columella rows of the root cap were measured with a light microscope and a digital video camera (Olympus) (DP-11). The images were analyzed using the SigmaScan Pro (Jandel Scientific Software) program.

\subsubsection{Determination of Mitotic Index}

For estimation of primary root apical meristem cells' mitotic activity, the roots were fixed in acetic acid:ethanol mixture (1:3). After 4 days of fixation, roots were washed from the mixture; the apical meristem zone was excised and dyed with acetocarmine, whereas cell walls were macerated with chloral hydrate [54]. In temporary squash preparations by a light microscope (Nikon Eclipse 80i), 6 cell mitoses phases were counted and mitotic index (MI) calculated. MI-cell number in mitosis per 1000 cells of the analyzed object (expressed in per mille $\%$ oo $)$. MI $=(\mathrm{M} / \mathrm{N}) 1000$, where $\mathrm{M}$-number of mitoses, $\mathrm{N}$-cell number. For each variant, 20 primary root apical meristems were analyzed.

\subsection{Statistical Analysis}

Tests were provided with three biological replicates. For morphometrical measurements, roots of 40 seedlings were analyzed for each variant. The data presented are mean values \pm standard deviation of three experiments with four replicates in each. The data were statistically examined using analysis of variance (ANOVA) and tested for significant mean differences $(p<0.05)$ using Tukey's test. 


\section{Conclusions}

Elevated temperature impacted the formation of root architecture of two lupine species while influencing their invasiveness.

During the early stages of growth, the spatial orientation of the initial roots was temperature-dependent: at $25^{\circ} \mathrm{C}$, the angle of curvature of the initial roots of L. polyphyllus was closer to the gravity vector than that at $30^{\circ} \mathrm{C}$, while L. luteus were better oriented towards the gravity vector at $30^{\circ} \mathrm{C}$.

The dynamics of the gravitropic response of initial roots to $90^{\circ}$ reorientation confirmed that the gravitropic bending of L. luteus roots was more intense at $30^{\circ} \mathrm{C}$; meanwhile, $L$. polyphyllus was at $25^{\circ} \mathrm{C}$.

The simulated warming $\left(5^{\circ} \mathrm{C}\right)$ had an effect on L. polyphyllus root formation: the mitotic index of cell division in the root apical meristem was reduced by $12 \%$ at $30{ }^{\circ} \mathrm{C}$ compared to $25^{\circ} \mathrm{C}$.

After 30 days of cultivation at different temperatures, the root system of the invasive lupine was better developed at $25^{\circ} \mathrm{C}$, whereas the root size of the non-invasive lupine increased at $30^{\circ} \mathrm{C}$.

The current study provides important information on the effect of elevated temperature on the formation of plant root architecture and suggests that global warming is altering the invasiveness of alien species through changes in root architecture.

Author Contributions: Conceptualization, S.J. and V.G.; methodology, D.Š. and V.G.; formal analysis, S.J. and E.J.-B.; investigation, V.G. and D.Š.; data curation, S.J. and V.G.; writing-original draft preparation, V.G.; visualization, D.Š., writing—review and editing, E.J.-B. and S.J.; supervision, S.J. All authors have read and agreed to the published version of the manuscript.

Funding: This research was supported by the Nature Research Centre R\&D III programme.

Data Availability Statement: The data supporting reported results can be found in scientific reports of the Laboratory of Plant Physiology of Institute of Botany of Nature Research Centre, where archived datasets generated during the study are included.

Acknowledgments: We thank the staff of the Laboratory of Plant Physiology of the Nature Research Centre for support and help provided.

Conflicts of Interest: The authors declare no conflict of interest.

\section{References}

1. Alexander, J.M.; Diez, J.M.; Levine, J.M. Novel competitors shape species' responses to climate change. Nature 2015, 525, 515-518. [CrossRef]

2. Luo, H.; Xu, H.; Chu, C.; He, F.; Fang, S. High temperature can change root system architecture and intensify root interactions of plant seedlings. Front. Plant Sci. 2020, 11, 160. [CrossRef] [PubMed]

3. Lynch, J. Root architecture and plant productivity. Plant Phys. 1995, 109, 7-13. [CrossRef] [PubMed]

4. Rubinigg, M.; Wenisch, J.; Elzenga, J.T.M.; Stulen, I. NaCI salinity affects lateral root development in Plantago maritima. Func. Plant Biol. 2004, 3, 775-780. [CrossRef] [PubMed]

5. Radville, L.; McCormack, M.L.; Post, E.; Eissenstat, D.M. Root phenology in a changing climate. J. Exp. Bot. 2016, 67, 3617-3628. [CrossRef]

6. Hayes, S.; Schachtschabel, J.; Mishkind, M.; Munnik, T.; Arisz, S.A. Hot topic: Thermosensing in plants. Plant Cell Environ. 2020, 44, 2018-2033. [CrossRef]

7. Ma, Z.; Chang, S.X.; Bork, E.W.; Steinaker, D.F.; Wilson, S.D.; White, S.R. Climate change and defoliation interact to affect root length across northern temperate grasslands. Funct. Ecol. 2020, 34, 2611-2621. [CrossRef]

8. Koevoets, I.T.; Venema, J.H.; Elzenga, J.T.M.; Testerink, C. Roots withstanding their environment: Exploiting root system architecture responses to abiotic stress to improve crop tolerance. Front. Plant Sci. 2016, 7, 1335. [CrossRef]

9. De Lima, C.F.F.; Kleine-Vehn, J.; de Smet, I.; Feraru, E. Getting to the root of belowground high temperature responses in plants. J. Exp. Bot. 2021, 72, 7404-7413.

10. Ribeiro, P.R.; Fernandez, L.G.; de Castro, R.D.; Ligterink, W.; Hilhorst, H.W. Physiological and biochemical responses of Ricinus communis seedlings to different temperatures: A metabolomics approach. BMC Plant Biol. 2014, 14, 223. [CrossRef]

11. Hund, A.; Fracheboud, Y.; Soldati, A.; Stamp, P. Cold tolerance of maize seedlings as determined by root morphology and photosynthetic traits. Eur. J. Agron. 2008, 28, 178-185. [CrossRef] 
12. Calleja-Cabrera, J.; Boter, M.; Oñate-Sánchez, L.; Pernas, M. Root growth adaptation to climate change in crops. Front. Plant Sci. 2020, 11, 544. [CrossRef] [PubMed]

13. Sattelmacher, B.; Marschner, H.; Kühne, R. Effects of the temperature of the rooting zone on the growth and development of roots of potato (Solanum tuberosum). Ann. Bot. 1990, 65, 27-36. [CrossRef]

14. Joshi, M.; Fogelman, E.; Belausov, E.; Ginzberg, I. Potato root system development and factors that determine its architecture. J. Plant Physiol. 2016, 205, 113-123. [CrossRef]

15. Pardales, J.R.; Kono, Y.; Yamauchi, A. Epidermal cell elongation in sorghum seminal roots exposed to high root-zone temperature Plant Sci. 1992, 81, 143-146. [CrossRef]

16. Rogers, E.D.; Benfey, P.N. Regulation of plant root system architecture: Implications for crop advancement. Curr. Opin. Biotechnol. 2015, 32, 93-98. [CrossRef]

17. Gray, S.B.; Brady, S.M. Plant developmental responses to climate change. Dev. Biol. 2016, 419, 64-77. [CrossRef]

18. Forbes, P.; Black, K.; Hooker, J. Temperature-induced alteration to root longevity in Lolium perenne. Plant Soil. 1997, 190, 87-90. [CrossRef]

19. Seiler, G.J. Influence of temperature on primary and lateral root growth of sunflower seedlings. Environ. Exp. Bot. 1998, 40, 135-146. [CrossRef]

20. Bardgett, R.D.; Mommer, L.; de Vries, F.T. Going underground: Root traits as drivers of ecosystem processes. Trends Ecol. Evol. 2014, 29, 692-699. [CrossRef]

21. Nagel, K.A.; Kastenholz, B.; Jahnke, S.; van Dusschoten, D.; Aach, T.; Mühlich, M.; Truhn, D.; Scharr, H.; Terjung, S.; Walter, A.; et al. Temperature responses of roots: Impact on growth, root system architecture and implications for phenotyping. Funct. Plant Biol. 2009, 36, 947. [CrossRef]

22. Aidoo, M.K.; Bdolach, E.; Fait, A.; Lazarovitch, N.; Rachmilevitch, S. Tolerance to high soil temperature in foxtail millet (Setaria italica L.) is related to shoot and root growth and metabolism. Plant Physiol. Biochem. 2016, 106, 73-81. [CrossRef]

23. Wani, S.H.; Kumar, V.; Saroj, V.S.; Sah, K. Phytohormones and their metabolic engineering for abiotic stress tolerance in crop plants. Crop J. 2016, 4, 162-176. [CrossRef]

24. Lucas, M.; Godin, C.; Jay-Allemand, C.; Laplaze, L. Auxin fluxes in the root apex co-regulate gravitropism and lateral root initiation. J. Exp. Bot. 2008, 59, 55-66. [CrossRef]

25. Miyazawa, Y.; Takahashi, H. Molecular mechanisms mediating root hydrotropism: What we have observed since the rediscovery of hydrotropism. J. Plant Res. 2020, 133, 3-14. [CrossRef]

26. Morita, M.T. Directional gravity sensing in gravitropism. Annu. Rev. Plant Biol. 2010, 61, 705-720. [CrossRef] [PubMed]

27. Muthert, L.W.F.; Izzo, L.G.; van Zanten, M.; Aronne, G. Root tropisms: Investigations on Earth and in space to unravel plant growth direction. Front. Plant Sci. 2020, 10, 1807. [CrossRef] [PubMed]

28. Moulia, B.; Fournier, M. The power and control of gravitropic movements in plants: A biomechanical and systems biology view. J. Exp. Bot. 2009, 60, 461-486. [CrossRef] [PubMed]

29. Taniguchi, M.; Furutani, M.; Nishimura, T.; Nakamura, M.; Fushita, T.; Iijima, K.; Baba, K.; Tanaka, H.; Toyota, M.; Tasaka, M.; et al. The Arabidopsis LAZY1 family plays a key role in gravity signalling within statocytes and in branch angle control of roots and shoots. Plant Cell 2017, 29, 1984-1999. [CrossRef] [PubMed]

30. Morita, M.T.; Tasaka, M. Gravity sensing and signaling. Curr. Opin. Plant Biol. 2004, 7, 712-718. [CrossRef]

31. Leitz, G.; Kang, B.H.; Schoenwaelder, M.E.; Staehelin, L.A. Statolith sedimentation kinetics and force transduction to the cortical endoplasmic reticulum in gravity-sensing Arabidopsis columella cells. Plant Cell 2009, 21, 843-860. [CrossRef]

32. Strohm, A.K.; Baldwin, K.L.; Masson, P.H. Molecular mechanisms of root gravity sensing and signal transduction. Wiley Interdiscip. Rev. Dev. Biol. 2012, 1, 276-285. [CrossRef]

33. Sato, E.M.; Hijazi, H.; Bennett, M.J.; Vissenberg, K.; Swarup, R. New insights into root gravitropic signalling. J. Exp. Bot. 2015, 66, 2155-2165. [CrossRef] [PubMed]

34. Masson, P.H.; Tasaka, M.; Morita, M.T.; Guan, C.; Chen, R.; Boonsirichai, K. Arabidopsis thaliana: A model for the study of root and shoot gravitropism. Arab. Book 2002, 1, e0043. [CrossRef]

35. Nakamura, M.; Nishimura, T.; Morita, M.T. Gravity sensing and signal conversion in plant gravitropism. J. Exp. Bot. 2019, 70, 3495-3506. [CrossRef]

36. Friml, J.; Wisniewska, J.; Benkova, E.; Mendgen, K.; Palme, K. Lateral relocation of auxin efflux regulator PIN3 mediates tropism in Arabidopsis. Nature 2002, 415, 806-809. [CrossRef]

37. Ma, Z.; Hasenstein, K.H. The onset of gravisensitivity in the embryonic root of flax. Plant Physiol. 2006, 140, 159-166. [CrossRef] [PubMed]

38. Domisch, T.; Finér, L.; Lehto, T.; Smolander, A. Effect of soil temperature on nutrient allocation and mycorrhizas in Scots pine seedlings. Plant Soil 2002, 239, 173-185. [CrossRef]

39. Martins, S.; Montiel-Jorda, A.; Cayrel, A.; Huguet, S.; Roux, C.P.; Ljung, K.; Vert, G. Brassinosteroid 720 signaling-dependent root responses to prolonged elevated ambient temperature. Nat. Commun. 2017, 8, 309. [CrossRef] [PubMed]

40. Merkys, A.I. Geotropic Reaction of Plants, 1st ed.; Mintis: Vilnius, Lithuania, 1973; p. 264. (In Russian)

41. Su, S.H.; Gibbs, N.M.; Jancewicz, A.L.; Masson, P.H. Molecular mechanisms of root gravitropism. Curr. Biol. 2017, 27, R964-R972. [CrossRef] [PubMed]

42. Leyser, O. Auxin signaling. Plant Physiol. 2018, 176, 465-479. [CrossRef] [PubMed] 
43. Küpers, J.J.; Oskam, L.; Pierik, R. Photoreceptors regulate plant developmental plasticity through auxin. Plants 2020, 9, 940. [CrossRef] [PubMed]

44. Zhang, Y.; Xiao, G.; Wang, X.; Zhang, X.; Friml, J. Evolution of fast root gravitropism in seed plants. Nat. Commun. 2019, 10, 3480. [CrossRef] [PubMed]

45. Pilet, P.E. Importance of the cap cells in maize root gravireaction. Planta 1982, 156, 95-96. [CrossRef]

46. Ransom, J.S.; Moore, R. Geoperception in primary and lateral roots of Phaseolus vulgaris (Fabaceae). I. Structure of columella cells. Am. J. Bot. 1983, 70, 1048-1056. [CrossRef] [PubMed]

47. Kawata, S.; Katano, M.; Yamazaki, K. The growing directions and the geotropic responses of rice crown roots. Jpn. J. Crop Sci. 1980, 49, 301-310. [CrossRef]

48. Verbelen, J.P.; De Cnodder, T.; Le, J.; Vissenberg, K.; Baluška, F. The root apex of Arabidopsis thaliana consists of four distinct zones of cellular activities: Meristematic zone, transition zone, fast elongation zone, and growth terminating zone. Plant Signal. Behav. 2006, 1, 296-304. [CrossRef]

49. Casimiro, I.; Marohant, A.; Bhalero, R.P.; Beeckmann, T.; Dhoope, S.; Swarup, R.; Graham, N.; Inze, D.; Sandberg, G.; Casero, P.J.; et al. Auxin transport promotes Arabidopsis lateral root initiation. Plant Cell 2001, 13, 843-852. [CrossRef]

50. Overvoorde, P.; Fukaki, H.; Beeckman, T. Auxin control of root development. Cold Spring Harb. Perspect. Biol. 2010,2 , a001537. [CrossRef]

51. $\mathrm{Wu}, \mathrm{Q}$; Pagès, L.; $\mathrm{Wu}, \mathrm{J}$. Relationships between root diameter, root length and root branching along lateral roots in adult, field-grown maize. Ann. Bot. 2016, 117, 379-390. [CrossRef] [PubMed]

52. CABI's Invasive Species Compendium. Available online: https:/ / www.cabi.org/isc/datasheet/31710 (accessed on 5 January 2022).

53. Wang, R.L.; Zeng, R.S.; Peng, S.L.; Chen, B.M.; Liang, X.T.; Xin, X.W. Elevated temperature may accelerate invasive expansion of the liana plant Ipomoea cairica. Weed Res. 2011, 51, 574-580. [CrossRef]

54. Paulauskas, A.; Slopšytè, G.; Morkūnas, V. Methods and Practicals of General Genetic Investigations, 1st ed.; Infrorastras: Vilnius, Lithuaniai, 2003; pp. 23-30. (In Lithuania) 